\title{
TUTURAN DIREKTIF GURU DALAM PEMBELAJARAN SEBAGAI SARANA PENDIDIKAN KARAKTER
}

\author{
Sri Muryati dan Titik Sudiatmi \\ Universitas Veteran Bangun Nusantara Sukoharjo Indonesia \\ E-mail: srimuryati411@gmail.com
}

\begin{abstract}
Abstrak: Pembelajaran tatap muka yang digantikan dengan pembelajaran daring dengan adanya pandemi Covid-19 telah mengajarkan banyak hal. Aspek nonverbal dalam interaksi guru-siswa dan suasana kelas yang setiap warganya saling mendukung dan memotivasi dalam membentuk siswa berkarakter kuat belum mendapat penggantinya. Tujuan penelitian ini untuk mendeskripsikan bentuk-bentuk pendidikan karakter yang terkondisikan dengan tuturan direktif guru dalam pembelajaran di Taman Kanak-Kanak (TK). Metode penelitian ini yaitu metode kualitatif deskriptif. Data penelitian berujud tuturan direktif guru dalam pembelajaran yang mengondisikan penguatan pendidikan karakter siswa TK. Untuk pengumpulan datanya digunakan teknik rekam, teknik simak, dan teknik catat. Analisis datanya menggunakan langkah-langkah: mengidentifikasi tuturan guru yang merupakan tuturan direktif, mengidentifikasikan tuturan direktif yang mendorong penguatan pendidikan karakter, dan mengidentifikasikan penggunaan metode pendidikan karakter oleh guru. Simpulan penelitian ini yaitu bahwa tuturan direktif guru dalam pembelajaran di TK dapat menjadi sarana penguatan pendidikan karakter (1) cinta terhadap Tuhan Yang Maha Esa; (2) disiplin; (3) jujur; (3) mandiri; (4) kreatif; (5) kerja keras; (6) percaya diri; (7) toleransi dan cinta damai; dan (9) tanggung jawab. Metode pendidikan karakter yang diterapkan guru yaitu metode penanaman nilai, keteladanan nilai, dan keterampilan nilai.
\end{abstract}

Kata Kunci: tuturan direktif, pembelajaran, pendidikan karakter

\section{TEACHER'S DIRECTIVE SPEAKING IN LEARNING AS CHARACTER EDUCATION MEANS}

\begin{abstract}
Face-to-face learning which has been replaced by online learning due to the Covid-19 pandemic has taught many things. The nonverbal aspects of teacher-student interaction and the class atmosphere where each people support each other with strong character have not been replaced. The purpose of this study is to describe the forms of character education conditioned by the directive speech of the teacher in learning in kindergarten. This research method is descriptive qualitative method. The data of this research were in the form of directive speech of the teacher in learning which conditions the strengthening of the character education of kindergarten children. The data collection used recording techniques, listening techniques, and note taking techniques. The data analysis used the following steps: identifying the teacher's speech which is directive speech, identifying directive speech that can encourage the strengthening of character education and identifying the use of character education methods by teachers. The conclusion of the study that the directive speech of teachers in kindergarten learning can be a means of strengthening character education (1) love for God Almighty, (2) discipline, (3) honest, (4) independent, (5) creative, (6) hard work, (7) self-confidence, (7) tolerance and peace-loving, and (9) responsibility. Futhermore, character education method applied by the teacher is the method of establishing values, exemplary values, and value skills.
\end{abstract}

Keywords: directive speech, learning, character education

\section{PENDAHULUAN}

Proses pembelajaran telah lama dipahami sebagai interaksi pembelajaran tatap muka di kelas baik di TK, SD, SMP, SMA, maupun di perguruan tinggi. De- ngan pandemi Covid-19 hal tersebut menjadi berubah dan pembelajaran daring menjadi penggantinya. Namun, banyak pihak, utamanya para siswa, yang merindukan pembelajaran tatap muka. Efektifnya 
pembelajaran tatap muka dapat dirasakan banyak pihak terutama siswa. Berdasarkan penuturan seorang siswa sekolah dasar kelas rendah (bernama KA) pada pertengahan bulan Desember 2020, pembelajaran di sekolah sangat dirindukan karena dapat bertemu dengan teman untuk bermain dan belajar bersama guru tentang banyak hal secara langsung. Sekarang ini baru dicarikan format pengganti yang efektif dalam bentuk pembelajaran daring (dalam jaringan). Penelitian ini memaparkan kondisi pembelajaran luring (luar jaringan) yang pernah dilaksanakan.

Peran guru dalam pendidikan di Taman Kanak-Kanak (TK) sangat dominan karena perkembangan siswa TK masih relatif tergantung pada pendidik. Hal ini disebabkan karakteristik anak usia taman kanak-kanak sekitar usia 5-6 tahun masuk tahapan realisme moral. Pada tahap ini (anak usia 4-7 tahun) menurut Piaget (Syah, 2008), cirinya bahwa setiap perbuatan pada dasarnya mengikuti aturan dan jika melanggar otomatis mendapat sanksi. Pada tahap ini anak mempelajari nilai-nilai moral tidak berdasar pada kesepakatan tetapi pada peraturan.

Sesuai dengan tingkat perkembangannya, ada strategi yang cocok diterapkan dalam pembelajaran moral. Syah (2008, p. 123) menyatakan bahwa belajar kebiasaan memiliki tujuan memperoleh sikap dan kebiasaan perbuatan baru yang selaras dengan norma dan tata nilai moral yang berlaku. Strategi pembelajaran yang dapat diterapkan adalah menggunakan perintah, suri teladan, pengalaman khusus, hukuman, dan ganjaran.

Perintah dapat digunakan sebagai strategi pembelajaran sikap, moral, dan tata nilai sehingga penggunaan tindak tutur direktif dalam interaksi pembelajaran relevan digunakan. Penggunaan tindak tu- tur direktif dalam interaksi pembelajaran di TK perlu dikaji dan dibahas untuk mengembangkan proses dan interaksi pembelajaran sikap dan nilai secara efektif. Rustono (1999, p. 38) menyatakan bahwa tindak tutur (tuturan) direktif adalah penggunaan bahasa yang dimaksudkan penuturnya agar mitra tutur melakukan tindakan yang disebutkan dalam tuturan.

Karakter seseorang dapat berkembang secara baik jika mendapat penguatan secara tepat dengan pendidikan. Dalam hal ini pendidikan formal menjadi penting peranannya dalam mengembangkan karakter. Interaksi pembelajaran di kelas termasuk di TK juga merupakan sarana penanaman karakter. Selanjutnya Kirschenbaum (1995) menyampaikan bahwa metode pendidikan karakter meliputi penanaman nilai, keteladanan nilai, fasilitasi nilai, dan keterampilan nilai. Penanaman nilai dapat dilakukan dengan berbagai cara seperti penjelasan, petunjuk atau peraturan, sanksi, pembiasaan, dan apel.

Ada beberapa penelitian tentang pendidikan karakter yang dilakukan oleh beberapa ahli di antaranya sebagai berikut. Pertama, penelitian yang dilakukan oleh Listiawati (2018). Penelitian studi kasus ini menyimpulkan bahwa penguatan pendidikan karakter dilaksanakan di SDN 09 Mataram melalui berbagai kegiatan. Beberapa hambatan diatasi dengan perbaikan jadwal, komunikasi, koordinasi antarpihak sekolah dan orang tua, serta penyesuaian konsep kurikulum 2013 dan penguatan pendidikan karakter sehingga selain 4C (critical thinking, communication skills, creativity, dan cooperation) perlu dipertimbangkan peningkatan 3C (communication, coordination, dan cooperation). Implementasi penguatan pendidikan karakter didukung oleh kepemimpinan kepala sekoolah, war- 
ga sekolah, dan kerja sama sekolah dengan masyarakat dan lembaga lainnya.

Kedua, penelitian yang dilakukan oleh Mariyana (2018). Penelitian ini menyimpulkan bahwa (1) kompetensi guru di lapangan secara keseluruhan baik; (2) pelaksanaan pembelajaran berbasis pendidikan karakter oleh guru di lapangan belum ideal; dan (3) kompetensi guru dalam pembelajaran berbasis pendidikan karakter perlu ditingkatkan.

Ketiga, penelitian yang dilakukan oleh Efendi (2020). Hasil penelitian ini yaitu: (1) nilai-nilai karakter utama dalam Pendidikan karakter meliputi: kemandirian, semangat kebangsaan, cinta tanah air, cinta damai, gemar membaca, dan kejujuran; (2) pengekspresian nilai-nilai karakter dilakukan dengan (a) penyampaian langsung dengan cara pendeskripsian karakter, tindakan, dan perilaku tokoh oleh pencerita, dan (b) penyampaian tidak langsung dengan cara paparan sikap dan tingkah laku tokoh menghadapi peristiwa dan konflik.

Penelitian ini berbeda dengan ketiga penelitian tersebut, karena penelitian ini didasarkan pada tuturan direktif guru dalam pembelajaran di TK dengan variasinya. Tuturan direktif tersebut dibahas fungsinya sebagai sarana pengondisian penguatan karakter siswa. Kemudian diidentifikasi metode pendidikan karakter yang diterapkan dengan penggunaan tuturan direktif tersebut.

Kemendikbud (2016, p. 17) mendeskripsikan bahwa karakter merupakan ciri khas seseorang atau sekelompok orang yang mengacu pada serangkaian sikap (attitudes), perilaku (behaviors), motivasi (motivasions), dan keterampilan (skills) sebagai manifestasi dari nilai, kemampuan, kapasitas moral, dan ketegaran dalam menghadapi kesulitan dan tantangan. Tan- tangan dan kesulitan selalu mengiringi hidup dalam keseharian setiap individu yang berkiprah dalam pembelajaran, pekerjaan dan profesinya. Battistich (Listiawati, 2018) mengatakan bahwa karakter adalah realisasi salah satu perkembangan individu yang positif baik secara intelektual, sosial, emosional, dan etik. Adapun istilah yang dimunculkan Goleman (1995) untuk karakter ini adalah emotional intelligence.

Dari beberapa pendapat tersebut dapat dinyatakan bahwa karakter tidak tertanam dengan sendirinya tetapi melewati proses dengan internalisasi berbagai kebajikan yang diyakini dan digunakan sebagai landasan berpijak, bersikap, berpikir, dan bertindak sebagai bentuk realisasi dari perkembangan intelektual, sosial, emosional, dan etik. Dalam hal penanaman karakter, Affandi (2020) menyatakan bahwa penanaman karakter menjadi hal penting dalam pendidikan termasuk bagi anak usia dini dan bahkan perlu dilakukan sedini mungkin.

Pentingnya kurikulum disampaikan oleh Kemendiknas (2011) bahwa kurikulum adalah jantungnya pendidikan, karena itu seluruh aktivitas pendidik diselaraskan untuk memberikan perhatian yang lebih besar pada pendidikan budaya dan karakter bangsa. Dengan hal ini, guru atau pendidik dituntut untuk memrogramkan pendidikan karakter secara terintegrasi dalam pembelajaran di kelas sehingga setiap aktivitas pendidik merupakan penerapan pendidikan karakter.

Pembelajaran di TK diungkapkan oleh Masitoh (2012) bahwa interaksi pembelajaran yang diterapkan berlandaskan program yang ada bertujuan membentuk perilaku dengan pembiasaan. Pembentukan perilaku dimaksud dilakukan secara rutin dalam keseharian sehingga tertanam kebiasaan baik (karakter baik). Pengem- 
bangan perilaku ini meliputi pengembangan moral dan nilai-nilai agama, pengembangan sosial, pengembangan emosional, dan kemandirian

Pengembangan moral dan nilai-nilai agama bertujuan meningkatkan ketakwaan kepada Tuhan Yang Maha Esa dan membina sikap anak dalam rangka meletakkan dasar menjadi warga negara yang baik. Pengembangan sosial, pengembangan emosional, dan kemandirian bertujuan untuk dapat berinteraksi dengan sesama maupun dengan orang dewasa dengan baik, membina anak agar mampu mengendalikan emosinya secara wajar, serta dapat menolong dirinya sendiri dalam rangka kecakapan hidup. Adapun kiat yang bisa dilakukan guru adalah dengan mengajak anak berkomunikasi dan berinteraksi sehingga anak memberikan respons yang dapat menumbuhkan dan mengembangkan kompetensi yang diharapkan.

Berdasarkan pedoman dari Kemendikbud (2017), dirumuskan ada 18 nilai pembentuk karakter bangsa yang tercakup dalam 5 karakter utama, yaitu religius, nasionalis, mandiri, gotong-royong, dan integritas. Sesuai dengan tingkat perkembangan siswa TK, Mariyana (2018) menyatakan bahwa untuk membentuk karakter anak usia dini sesuai dengan karakter prakondisi yang telah terbentuk maka pendidikan karakter untuk anak usia dini meliputi: (1) cinta terhadap Tuhan Yang Maha Esa; (2) toleransi dan cinta damai; (3) disiplin, (4) jujur; (5) percaya diri; (6) mandiri; (7) kreatif; (8) kerja keras; dan (9) tanggung jawab.

Lickona (1991) juga Fransisca \& Clara (2015) menyatakan bahwa pendidikan karakter menekankan pentingnya tiga komponen karakter yang baik, yaitu pengetahuan tentang moral, perasaan moral, dan tindakan moral. Bagi anak. Hal tersebut diperlukan agar anak mampu memahami, merasakan dan mengerjakan sekaligus nilai-nilai kebajikan. Pendidikan karakter merupakan sebuah sistem penanaman nilai-nilai karakter ke dalam diri semua warga sekolah yang mencakupi komponen pemahaman, keinginan untuk melakukan, dan tindakan untuk melaksanakan nilainilai tersebut.

Untuk mencapai tujuan pembelajaran di taman kanak kanak, kiat guru berinteraksi dengan anak dengan menggunakan tuturan direktif merupakan salah satu teknik yang ditempuh. Cunningsworth (Tarigan, 2009, p. 41) menyatakan bahwa pemerian yang komprehensif dan eksplisit mengenai tindak ujar (tindak tutur) akan memiliki nilai yang penting bagi guru dan siswa dalam interaksi belajar mengajar.

\section{METODE}

Penelitian ini merupakan penelitian kualitatif deskriptif yang data-datanya berujud tuturan penggunaan bahasa oleh guru dalam pembelajaran. Penelitian ini menggambarkan fenomena tuturan guru apa adanya untuk diinterpretasikan sesuai dengan tujuan yang telah ditetapkan yaitu tentang jenis tuturan direktif yang merupakan sarana penguatan pendidikan karakter. Data dalam penelitian ini berupa tuturan direktif guru dalam pembelajaran yang merupakan sarana penguatan pendidikan karakter di Taman Kanak-Kanak Aisyiah Karangwuni, Polokarto, Kabupaten Sukoharjo.

Langkah-langkah penelitian untuk memecahkan masalah mengikuti pendapat Sudaryanto (2015) meliputi: (1) tahap penyediaan data; (2) tahap analisis data; dan (3) tahap penyajian hasil analisis data. Pada tahap penyediaan data ditempuh dengan berkolaborasi dengan guru TK. Pengumpulan data dilakukan dengan teknik simak-baca dan catat. Langkah-langkah yang 
ditempuh dalam pengumpulan data yaitu: (a) menyimak interaksi pembelajaran di Taman Kanak-Kanak dan merekamnya; (b) membuat transkripsi dengan menuliskan interaksi lisan tersebut; (c) membaca transkripsi; (d) melakukan pencatatan data yang dibutuhkan yaitu tentang tuturan direktif yang merupakan sarana penguatan pendidikan karakter.

Dalam menganalisis data penelitian ini, peneliti bertindak sebagai instrumen mengingat bahwa peneliti sebagai dosen/ guru bahasa yang juga memahami proses pembelajaran. Adapun teknik analisis data yang digunakan untuk memecahkan masalah tindak tutur ditempuh dengan metode padan dan metode agih. Metode padan digunakan untuk mengidentifikasi karakteristik tindak tutur dengan penentu mitra bicara yaitu siswa dengan penafsir lain yaitu peneliti. Selanjutnya, metode agih digunakan untuk mengidentifikasi tuturan direktif dengan penentu penanda kebahasaan tindak yang digunakan. Metode agih ini masih dilanjutkan dengan teknik lanjutan baca markah. Artinya, untuk mengidentifikasi tindak tutur direktif dilakukan dengan membaca pemarkah yang digunakan dalam tuturan. Untuk analisis tuturan direktif guru digunakan referensi yang disarikan dari Ibrahim (1993) bahwa tuturan direktif adalah tuturan yang bertujuan untuk menyuruh orang lain melakukan sesuatu. Tuturan direktif dapat diklasifikasikan dalam 7 kategori yaitu (1) mengajak; (2) pertanyaan; (3) menyuruh; (4) mengarahkan; (5) larangan; (6) pemberian izin; dan (7) nasihat.

Analisis data penelitian tentang tuturan direktif sebagai sarana penguatan pendidikan karakter dalam interaksi pembelajaran dilakukan dengan analisis isi. Data tentang tuturan-tuturan direktif guru diidentifikasi perannya dalam pembelajar- an sebagai sarana pengondisian karakter yang meliputi: (1) cinta terhadap Tuhan Yang Maha Esa; (2) toleransi dan cinta damai; (3) disiplin; (4) jujur; (5) percaya diri; (6) mandiri; (7) kreatif; (8) kerja keras; dan (9) tanggung jawab. Untuk menganalisis data yang diperoleh ditempuh cara tuturan direktif guru diidentifikasi perannya sebagai sarana penguatan pendidikan karakter dengan menggunakan indikator tertentu (Kemendiknas, 2010; Mariyana, 2018). Selanjutnya, analisis dilanjutkan dengan mengidentifikasi metode pendidikan karakter yang diterapkan guru dengan tuturan direktifnya berdasar teori Kirschenbaum (1995).

\section{HASIL DAN PEMBAHASAN}

Pada bagian hasil dan pembahasan ini diuraikan temuan dari hasil kajian tentang tuturan direktif sebagai sarana penanaman karakter bagi anak TK Aisyiah Karangwuni Polokarto Kabupaten Sukoharjo. Tidak semua temuan disajikan dalam bagian ini tetapi disajikan secara selektif namun representatif untuk mencapai tujuan kajian.

Hasil penelitian tentang tuturan direktif guru dalam pembelajaran yang menguatkan pendidikan karakter siswa TK didasarkan pada bentuk penguatan pendidikan karakter (Kemendiknas, 2010; Mariyana, 2018) serta metode dan teknik pendidikan karakter (Prasetyo dan Marzuki, 2016). Metode dimaksud yakni (1) penanaman nilai; (2) keteladanan nilai; (3) fasilitasi nilai; dan (4) keterampilan nilai. Adapun hasil penelitian tersebut disajikan dalam Tabel 1.

Data yang sudah dideskripsikan tersebut akan dibahas dalam (1) jenis tuturan direktifnya; (2) bentuk penguatan karakter yang terkondisikan oleh tuturan direktif tersebut; dan (3) metode pendidikan karakter yang diterapkan guru berdasarkan tu- 
turan direktifnya. Berdasarkan hasil penelitian yang telah dipaparkan di atas berikut ini akan dibahas bentuk-bentuk pendidikan karakter yang terkondisikan dengan tuturan direktif guru dalam pembelajaran di TK. Dari tuturan direktif inilah dapat dianalisis nilai-nilai karakter yang termuat di dalamnya (Meilani, 2020).

\section{Tabel 1. Bentuk dan Metode Pendidikan Karakter dalam Tuturan Direktif Guru}

\begin{tabular}{|c|c|c|c|c|c|}
\hline \multirow{2}{*}{ No } & \multirow{2}{*}{$\begin{array}{l}\text { Bentuk Pendidikan } \\
\text { Karakter }\end{array}$} & \multicolumn{3}{|c|}{ Komponen Pembentukan Karakter } & \multirow{2}{*}{ Tuturan Direktif Guru } \\
\hline & & Pengetahuan & Keinginan & Tindakan & \\
\hline & $\begin{array}{l}\text { Cinta terhadap Tuhan } \\
\text { Yang Mahaesa }\end{array}$ & 1 & 1 & 3 & $\begin{array}{l}\text { Menyuruh, Mengajak, Pertanyaan, } \\
\text { Larangan, Nasihat, Mengajak }\end{array}$ \\
\hline & $\begin{array}{l}\text { Toleransi dan cinta } \\
\text { damai }\end{array}$ & - & - & 6 & Larangan, Nasihat, Membolehkan \\
\hline & Disiplin & - & - & 8 & $\begin{array}{l}\text { Mengajak, Menyuruh, Pertanyaan, } \\
\text { Larangan }\end{array}$ \\
\hline & Jujur & - & - & 2 & Menyuruh \\
\hline & Percaya diri & 1 & - & 5 & Menyuruh, Pertanyaan \\
\hline & Mandiri & 1 & - & 5 & $\begin{array}{l}\text { Mengajak, Menyuruh, } \\
\text { Mengarahkan, Nasihat, Larangan }\end{array}$ \\
\hline & Kreatif & - & - & 3 & $\begin{array}{l}\text { Menyuruh, Mengarahkan, } \\
\text { Mengajak }\end{array}$ \\
\hline & Kerja keras & - & - & 10 & $\begin{array}{l}\text { Mengarahkan, Mengajak, } \\
\text { Menyuruh, Nasihat, Membolehkan }\end{array}$ \\
\hline 9. & Tanggung jawab & 1 & - & 3 & Pertanyaan, Menyuruh \\
\hline
\end{tabular}

1. Tuturan Direktif Sarana Penguatan Karakter 'Cinta terhadap Tuhan Yang Maha Esa'

Bentuk penguatan karakter cinta kepada Tuhan Yang Maha Esa yaitu berupa nilai-nilai yang didasarkan pada perilaku yang menunjukkan kepatuhan pada perintah dan larangan Tuhan Yang Maha Esa yang diterapkan dalam kehidupan seharihari (Kemendiknas, 2010; Mariyana, 2018). Tuturan direktif guru yang mengondisikan penguatan pendidikan karakter dimaksud yaitu:

(1) Hafalan dulu ya! Siapa yang pengin ikut balon masuk surga? Kalau pengin ikut syaratnya harus ngaji dulu yang serius biar dadi anak shaleh karo shalihah, siapa saja yang ikut?

(2) Kemarin Mbah buyute mas Satria yang meninggal, sekarang Mbahe mas Agam. Kalau ada orang meninggal kita mengucapkan apa?

(3) Coba kalau makan diam, jangan bersuara.

(4) Berdoa dahulu. Jika aku berdoa kuangkat tanganku, berdoa sungguh-sungguh agar dikabulkan. Segera berdoa adalah harta orang beriman. Di atas ada Allah, di samping ada malaikat.

(5) Ayo duduk dulu, sebelum makan berdoa dulu.

Kelimat data tersebut merupakan tuturan direktif yang merupakan penggunaan bahasa yang dimaksudkan agar siswa sebagai mitra tutur melakukan yang dimaksudkan guru. Tuturan direktif (1) $\mathrm{Ha}$ falan dulu ya! merupakan suruhan untuk melakukan tindakan membaca atau mengaji surat Alquran yang pelaksanaannya di awal dan di akhir pembelajaran. Tuturan direktif tersebut merupakan metode penanaman karakter pada siswa untuk patuh pada Tuhan Yang Maha Esa dengan pembiasaan. Tuturan direktif (2) berupa pertanyaan tentang pengetahuan siswa berkaitan yang diujarkan dan juga doa ketika ada orang meninggal sesuai ajaran agama Islam. Tuturan direktif ini merupakan metode penanaman karakter dengan teknik bertanya. 
Tuturan direktif (3) Coba kalau makan diam merupakan nasihat guru pada siswa pada saat makan bersama untuk mengikuti ajaran Islam dalam adab makan sesuai Hadis Nabi Muhammad saw., yaitu makan dengan diam tidak sambil berbicara dan juga tidak mengeluarkan suara. Pembentukan karakter dilakukan dengan metode penanaman nilai dengan teknik koreksi. Dan tuturan direktif (4) Berdoa dahulu termasuk suruhan (disampaikan dengan intonasi suruhan) untuk selalu berdoa sebelum melakukan kegiatan yang merupakan kepatuhan pada ajaran Islam. Ini merupakan metode penanaman karakter dengan teknik pembiasaan. Selanjutnya nasihat dengan menjelaskan untuk menerapkan adab dalam berdoa dengan mengangkat tangan, dengan sungguh-sungguh karena Allah dan malaikat mendampingi manusia dan agar termasuk orang beriman. Metode yang digunakan adalah penanaman karakter dengan teknik penjelasan.

Adapun ujaran (5) Ayo duduk dulu, sebelum makan berdoa dulu adalah tuturan direktif ajakan dengan penanda kata ayo dan guru pun juga duduk dan berdoa. Ajakan ini untuk mengikuti ajaran Islam dalam adab makan. Ini merupakan metode penanaman karakter untuk patuh pada ajaran Tuhan Allah dengan pembiasaan.

\section{Tuturan Direktif Sarana Penguatan Ka- rakter 'Toleransi dan Cinta Damai'}

Bentuk penguatan karakter toleransi dan cinta damai yaitu mengupayakan kebiasaan bersabar, tenggang rasa, dan menahan emosi \& keinginan (Kemendiknas, 2010; Mariyana, 2018). Tuturan direktifnya yakni:

(1) Halah halah aja main jorok-jorokan ngono kuwi, ndak tibo! (E e... tidak boleh dorong mendorong seperti itu, nanti mengakibatkan jatuh)

(2) Hayo hayo ora kandhan-kandhan, kandhankandhan kuwi ora apik! (Halo.. tidak boleh membicarakan orang, membicarakan orang lain itu tidak baik)

(3) Minum dulu, anak-anak boleh minum.

(4) Eh, ora oleh! Barisan masuk sesuai urutan. (E... tidak boleh (mendahului))

(5) Allon-alon, dhak utah! (Pelan-pelan saja membawanya biar tidak tumpah airnya)

(6) Coba yang masih punya lem banyak nanti berbagi, temannya dikasih sithik-sithik. (sithik-sithik $=$ sedikit-sedikit).

Kelima tuturan tersebut secara berturut-turut merupakan tuturan direktif yang merupakan perintah pada anak untuk melakukan sesuatu yang dimaksudkan tuturan. Tuturan (1) merupakan tuturan direktif larangan (adanya kata $a j a=$ jangan) bermain dorong mendorong. Tuturan direktif guru melarang siswa untuk tidak saling mendorong karena dapat berakibat jatuh dengan tujuan agar anak bersabar dan tenggang rasa yang merupakan karakter toleransi dan cinta damai. Penggunaan tuturan direktif tersebut merupakan penerapan metode penanaman nilai dengan petunjuk. Tuturan direktif (2) Kandhan-kandhan kuwi ora apik merupakan nasihat untuk tidak membicarakan orang lain (ora kandhan-kandhan) dengan bisik-bisik karena itu merupakan perilaku tidak baik yang dapat menimbulkan perpecahan, permusuhan. Tuturan direktif guru ini merupakan penerapan metode penanaman karakter toleransi dan cinta damai dengan teknik penjelasan.

Tuturan direktif (3) anak-anak boleh minum merupakan pemberian izin (dengan penanda boleh) untuk minum setelah melakukan aktivitas olah raga. Tuturan ini merupakan bentuk keteladanan guru bersikap toleran atau tenggang rasa pada anak yang haus untuk minum memenuhi kebutuhannya. Penggunaan tuturan direktif tersebut merupakan penerapan metode keteladanan. Dan tuturan direktif (4) Eh, ora oleh! (ora oleh = tidak boleh) berupa larangan untuk tidak mendahului siswa lain 
masuk kelas agar tidak timbul keributan. Dilanjut dengan petunjuk pada anak untuk masuk sesuai urutan. Guru ini menerapkan metode penanaman karakter dengan teknik pembiasaan untuk bersabar sebagai ujud karakter toleransi dan cinta damai.

Tuturan direktif (5) Alon-alon ndhak utah! merupakan nasihat untuk melakukan kegiatan membawa air sambil berjalan secara pelan-pelan agar air tidak tumpah (utah). Tuturan direktif ini diujarkan untuk mengondisikan anak agar bersabar dan menahan emosi dan keinginannya untuk segera sampai tujuan sebagai ujud pe-nanaman karakter toleransi dan cinta damai melalui petunjuk. Tuturan (6) Coba yang punya lem banyak nanti berbagi merupakan tuturan direktif nasihat untuk berbuat kebaikan dengan berbagi lem pada temannya yang membutuhkan. Dengan adanya tuturan sithik-sithik merupakan bentuk persuasi untuk mau berbagi (sedikit-sedikit saja). Tuturan direktif ini merupakan ujud penerapan metode penanaman karakter bersikap tenggang rasa dengan teknik penjelasan.

\section{Tuturan Direktif Sarana Penguatan Karakter 'Disiplin'}

Bentuk penguatan pendidikan karakter disiplin yaitu pembiasaan menjaga ketertiban dan keteraturan dalam beraktivitas. Tuturan direktif guru dalam pembelajaran merupakan upaya pembiasaan untuk melaksanakan aktivitas tertib dan teratur agar menciptakan kondisi yang mendukung pembelajaran dan pendidikan (Kemendiknas, 2010; Mariyana, 2018). Adapun tuturan direktif dalam pembelajaran yang mengondisikan perilaku dan sikap disiplin yakni:

(1) Ayo baris anak-anak!

(2) Ayo duduk sik ya! Diambil alat tulisnya dulu nggih. Astane sedheku, mirengke bu guru, mirsani papan tulis. Ayo madhepe papan tulis!
(Duduk dulu ya! Diambil alat tulisnya. Tangannya di atas meja tumpang menumpang, mendengarkan bu guru, memperhatikan papan tulis, Ayo menengok papan tulis!

(3) Afifa maem terus, Ayo sepatune dienggo! (Ayo sepatunya dipakai)

(4) Mari berkemas-kemas!

(5) Mas Vian makannya nanti lagi ya, mainannya buat bu guru apa disimpan di tas?

(6) Sik sik perjanjian sik, ora ngaji pulange keri apa dhisik? (Sebentar, berjanji dulu, kalau tidak mengaji pulang dulu atau belakangan?)

(7) Mundur sedikit pasukannya!

(8) Eh mosok yang menyiapkan sambil duduk, nanti ndhak pasukannya ikut duduk semua. (mosok=tidak seharusnya/tidak boleh)

Tuturan (1) Ayo baris anak-anak! Merupakan tuturan direktif ajakan (dengan penanda ayo dan guru juga ikut baris) untuk berbaris yang dilakukan setiap sebelum masuk kelas. Aktivitas berbaris sebelum masuk kelas bertujuan menjaga ketertiban suasana masuk kelas urut dan rapi. Tuturan direktif guru ini mengondisikan suasana tertib dan mengikuti aturan yang merupakan penerapan metode penanaman nilai karakter disiplin dengan pembiasaan. Tuturan direktif (2) merupakan suruhan untuk duduk dulu, lalu mengambil alat tulis, dan bersikap siap mendengarkan pelajaran yaitu memusatkan perhatian pada papan tulis sebagai pusat kegiatan siswa. Tuturan direktif ini mengondisikan anak untuk berlaku tertib dan teratur pada saat pelajaran berlangsung yang merupakan penerapan metode penanaman karakter disiplin dengan teknik petunjuk.

Tuturan direktif (3) bertujuan mengingatkan dan menyuruh siswa bernama Afifa untuk tidak makan di kelas selama pembelajaran berlangsung dan juga menyuruh untuk selalu memakai sepatu sesuai tata tertib yang berlaku. Tuturan direktif ini merupakan penerapan metode penanaman karakter pada siswa untuk menaati pada peraturan yang berlaku sebagai ujud karakter disiplin dengan teknik 
pembiasaan. Tuturan (4) Mari berkemaskemas! merupakan ajakan kepada siswa termasuk diri gurunya mengemasi peralatan pelajaran setiap akan pulang agar kelas rapi dan barang masing-masing anak tidak tertukar atau tertinggal. Tuturan direktif ini mengondisikan suasana tertib dan merupakan penerapan metode penanaman nilai disiplin dengan pembiasaan.

Tuturan direktif (5) merupakan suruhan yang bersifat mengingatkan dengan kata-kata secara halus untuk tidak makan ketika pelajaran berlangsung (makannya nanti lagi ya) dan diminta melanjutkannya nanti lagi. Tuturan ini juga menyuruh secara halus untuk berhenti bermain dengan memberi pilihan (mainannya buat bu guru atau disimpan di tas?) yang membuat siswa mau mengikuti. Hal ini dilakukan dalam mengikuti peraturan yang berlaku sehingga suasana kelas mendukung proses pembelajaran. Tuturan direktif ini mengondisikan anak atau kelas untuk tertib yang merupakan penerapan metode penanaman karakter disiplin dengan pembiasaan. Tuturan (6) merupakan tuturan direktif pertanyaan (dengan intonasi tanya) tentang peraturan yang ada (yang tidak mengaji pulang belakangan) untuk mengatur urutan kepulangan. Tuturan direktif ini merupakan pengondisian karakter tertib yang merupakan penerapan metode penanaman karakter disiplin dengan menerapkan peraturan.

Tuturan (7) Mundur sedikit pasukannya! merupakan suruhan pada pasukan untuk mundur sedikit agar barisan rapi. Kerapian barisan merupakan bentuk ketaatan pada peraturan tata tertib dan merupakan penerapan metode penanaman karakter disiplin dengan petunjuk. Tuturan (8) Eh, mosok yang menyiapkan sambil duduk merupakan tuturan direktif larangan (dengan mengatakan hal yang tidak lazim) menyiapkan pasukan sambil duduk dengan penyampaian yang persuasif. Larangan itu diikuti alasan guru secara persuasif yakni 'nanti pasukannya ikut duduk semua'. Hal ini membuat siswa menerima dengan ikhlas larangan sehingga suasana tertib tercipta demi kesiapan siswa dalam belajar dan merupakan penerapan metode penanaman karakter disiplin dengan teknik koreksi.

\section{Tuturan Direktif Sarana Penguatan Karakter 'Jujur'}

Bentuk penguatan karakter jujur yaitu pengkondisian pada upaya menjadikan diri dapat dipercaya dalam perkataan, tindakan, dan pekerjaan (Kemendiknas, 2010, p. 10; Mariyana, 2018). Tuturan direktif guru dalam pembelajaran yang mengondisikan perilaku dan sikap dapat dipercaya yaitu:

(1) (Coba lagunya ditambah satu lagi, lagu Ibu Kita Kartini), yang sudah hafal banter ya! (banter=menyanyi dengan keras).

(2) Janji lho ya pulange terakhir sing ora ngaji, sambil dilihat temannya yang nggak ngaji.

Tuturan (1) yang sudah hafal banter ya! merupakan suruhan bagi siswa yang sudah hafal untuk menyanyikan lagu dengan keras. Tuturan ini memotivasi dan mengondisikan siswa untuk bernyanyi dengan keras yang menunjukkan kemampuan yang sebenarnya (sudah hafal). Hal ini merupakan penerapan metode penanaman karakter jujur dengan teknik petunjuk. Tuturan (2) Janji tho ya, pulange terakhir sing ora ngaji merupakan suruhan yang mengingatkan siswa berjanji mematuhi peraturan sesuai fakta yaitu jujur pada diri sendiri untuk pulang bersama (ikut ngaji) atau pulang belakangan (tidak ikut ngaji). Demikian juga siswa dikondisikan untuk mengawasi (sebagai indikator kejujuran) teman yang tidak mengaji untuk dikenai sanksi pulang belakangan. Tuturan direktif 
ini mengondisikan siswa untuk menjadi orang yang dapat dipercaya yang merupakan penerapan metode penanaman karakter jujur dengan teknik mengingatkan adanya peraturan.

\section{Tuturan Direktif Sarana Penguatan Karakter 'Percaya Diri'}

Bentuk penguatan karakter percaya diri yaitu pengondisian dalam pemahaman terhadap kemampuan diri (Kemendiknas, 2010; Mariyana, 2018). Adapun tuturan direktif guru dalam pembelajaran yang menguatkan sikap percaya diri yakni:

(1) Ayo suaranya mana?

(2) Ayo sebutkan nama-nama bulan.

(3) Yang namanya sudah ditulis di balon engko ngajine banter. (Yang namanya sudah tertulis di balon nanti mengaji dengan keras)

(4) Apa warna benderanya anak-anak?

(5) Coba sekarang nyanyikan lagu Bendera Merah Putih!

(6) Coba aku pengin krungu suarane cah lanang ngaji. Surat at Tin nirokne bu guru satu satu. Nek ora enek suarane baleni ping sepuluh. (Coba aku ingin mendengarkan suara anak laki-laki mengaji. Surat at Tin, menirukan bu guru satu per satu. Kalau tidak ada suaranya diulang sepuluh kali).

(7) Mbak, jangan dimasukkan mulut jarine banyak kumane!

Tuturan (1) Ayo suaranya mana? merupakan tuturan direktif suruhan untuk mengaji dengan suara yang lebih keras sehingga dapat diketahui kemampuan diri (dalam mengaji: kelancaran, ketepatan, dan kebenaran pelafalannya). Tuturan direktif ini merupakan penerapan metode praktik keterampilan mengembangkan nilai atau karakter dengan teknik koreksi. Tuturan (2) Ayo sebutkan nama-nama bulan! Merupakan tuturan direktif suruhan untuk menampilkan kemampuannya menyebutkan nama-nama bulan. Tuturan direktif ini merupakan penerapan metode praktik keterampilan mengembangkan karakter dengan teknik keterampilan berkomunikasi.
Tuturan direktif (3) Yang namanya tertulis di balon, 'engko ngajine banter!' adalah suruhan untuk mengaji dengan keras (banter) bagi siswa yang namanya tertulis dalam balon. Dengan begitu siswa akan belajar memahami kemampuan diri dan memberikan kepercayaan diri bahwa hal itu membuat diri siswa lebih diperhitungkan dalam pembelajaran. Hal ini merupakan penerapan metode penanaman karakter dengan petunjuk. Tuturan (4) Apa warna benderanya anak-anak? berupa tuturan direktif pertanyaan dengan penanda kata tanya apa tentang warna bendera. Hal ini meminta siswa menjawab dengan menyampaikan pemahamannya dan akan memupuk karakter percaya diri. Dengan demikian, tuturan direktif ini menerapkan metode praktik keterampilan mengembangkan karakter dengan teknik keterampilan berkomunikasi.

Tuturan direktif (5) Coba sekarang nyanyikan lagu Bendera Merah Putih! merupakan suruhan untuk menyanyikan lagu dimaksud sehingga siswa menampilkan diri bernyanyi dalam rangka pemahaman diri apakah sudah hafal, ekspresi yang relatif tepat, penjiwaan yang relatif sesuai dan dapat memupuk karakter percaya diri siswa. Tuturan direktif ini menerapkan metode praktik keterampilan mengembangkan karakter dengan teknik keterampilan berkomunikasi. Tuturan direktif (6) Coba aku pengin krungu swarane cah lanang ngaji, merupakan suruhan pada siswa laki-laki untuk mengaji atau membaca hafalan Alquran dengan keras sehingga bisa didengar guru. Mengaji dengan keras membuat diri siswa memupuk dan mengembangkan rasa percaya diri dan memahami diri tentang kemampuannya dalam kelancaran membaca (dengan tartil), ketepatan pelafalan (sesuai makroj), dan kebenaran bacaan (tahsin). Dengan begitu, tuturan direktif ini 
merupakan ujud penerapan metode penanaman karakter dengan teknik petunjuk.

Adapun tuturan direktif (7) Mbak, jangan dimasukkan mulut jarinya, banyak kumane! merupakan larangan memasukkan jari ke mulut yang berarti sebagai peringatan karena dalam kuku jari terdapat kuman, yang dapat masuk ke dalam tubuh melalui mulut dan dapat menyebabkan sakit perut. Menurut Hidayani (2019), kebiasaan memasukkan jari ke mulut merupakan cerminan bahwa anak dalam kondisi cemas, tegang, takut. Tindakan pendidik yakni dengan menasihati secara bijak, halus, dan dapat diterima anak sehingga anak menjadi lebih bangga dan percaya diri. Tuturan direktif guru menasihati siswa sudah tepat. Tuturan direktif ini merupakan penerapan metode penanaman karakter percaya diri dengan teknik koreksi.

\section{Tuturan Direktif Sarana Penguatan Karakter 'Mandiri'}

Bentuk penguatan karakter mandiri yaitu berperilaku tidak tergantung pada orang lain. Penanaman nilai ini bertujuan untuk membantu membiasakan anak menentukan, melakukan, dan memenuhi kebutuhan sendiri tanpa bantuan orang lain (Kemendiknas, 2010; Mariyana, 2018). Tuturan direktif guru dalam pembelajaran yang mendukung yakni:

(1) Ayo masuk yo, alat tulisnya diambil.

(2) Nanti dibuka halaman 20, plastikke diguwak sampah. (...plastik dibuang tempat sampah)

(3) Mbak Alifa meneng sik (dari menangis) mengko istirahat ibu mrene. Engko dhak diisinisin kancane. (Mbak Alifa diam dulu dari menangis) nanti istirahat ibu ke sini, kalau nangis malah dicemooh teman).

(4) Coba kertas sisa guntingan dibuang sampah sendiri-sendiri.

Tuturan direktif (1) Ayo masuk yo, alat tulisnya diambil! adalah suruhan masuk kelas dan suruhan untuk mengambil alat tulis masing-masing untuk digunakan pada pembelajaran. Aktivitas mengambil alat tulis dapat dilakukan dengan baik jika siswa memahami tempat, alat tulis miliknya dan mungkin juga cara mengambilnya dalam rangka memenuhi kebutuhannya pada kegiatan yang akan dilaksanakan tanpa bantuan orang lain. Tuturan direktif tersebut merupakan penerapan metode penanaman karakter dengan teknik petunjuk. Tuturan direktif (2) Nanti dibuka halaman 20, plastike diguwak sampah merupakan suruhan untuk membuka buku masing-masing halaman 20 dengan melakukan sendiri. Bagi siswa TK membuka buku merupakan hal yang perlu dilatihkan agar dapat melakukannya sendiri di antaranya dengan cara guru memberi tahu angka 20 yang ditulis di papan tulis kemudian siswa mencari halaman yang bertuliskan angka tersebut di bagian halaman (tengah bawah) yang disebut guru. Selanjutnya terdapat suruhan untuk membuang plastik bungkus buku masing-masing ke tempat sampah yang ada di sekolahnya secara sendiri. Tuturan direktif ini merupakan penerapan metode praktik keterampilan mengembangkan nilai karakter.

Tuturan direktif (3) adalah nasihat untuk siswa yang bernama Alifa untuk diam dari menangis yang merupakan bentuk membantu diri untuk berhenti menangis. Hal itu masih dijelaskan secara persuasif oleh guru bahwa ibu akan segera datang menenangkan juga. Selain itu berhenti menangis juga agar tidak dicemooh teman. Tuturan direktif ini merupakan penerapan metode praktik keterampilan mengembangkan karakter mandiri.

Tuturan direktif (4) Coba kertas sisa guntingan dibuang sampah sendiri-sendiri! adalah suruhan (dengan penanda coba dan intonasi perintah) pada siswa untuk membuang sisa guntingan kertas ke tempat sampah sendiri. Artinya, siswa dikondisi- 
kan untuk melakukan pekerjaan membuang sampahnya sendiri. Tuturan direktif ini merupakan penerapan metode praktik keterampilan karakter.

\section{Tuturan Direktif Sarana Penguatan Karakter 'Kreatif'}

Bentuk penguatan karakter kreatif yaitu upaya yang mendorong anak melahirkan sesuatu yang baru baik gagasan maupun karya, mengombinasikan, dan memecahkan masalah (Kemendiknas, 2010; Mariyana, 2018). Tuturan direktif guru dalam pembelajaran untuk mendorong kreativitas siswa, yakni:

(1) Kalau sudah selesai diberi warna, yang disilang jangan diwarnai lho. Mewarnainya yang bagus.

(2) Sekarang game, gamenya engklek ya. Nanti 4-4 yang maju. Coba nanti kakinya diangkat yang satu sambil lompat-lompat.

Tuturan direktif (1) Kalau sudah selesai diberi warna .... Mewarnainya yang bagus merupakan suruhan dengan intonasi menyuruh. Tuturan direktif guru ini mendorong siswa berimajinasi membuat paduan warna dengan hasil yang padu (bagus) sesuai dengan daya kreasi, imajinasi, dan pengetahuan siswa dalam hal pewarnaan. Tuturan direktif ini merupakan penerapan metode praktik keterampilan karakter kreatif. Tuturan direktif (2) merupakan arahan pada siswa untuk bermain engklek (berlompat dengan satu kaki, kaki satunya lagi diangkat ke belakang). Dengan tuturan direktif ini, siswa dituntut untuk mengimajinasikan arahan guru agar dapat melaksanakan sesuai arahan berupa tantangan cara engklek. Selanjutnya dikatakan bahwa tuturan direktif tersebut merupakan penerapan metode praktik keterampilan karakter kreatif.

\section{Tuturan Direktif Sarana Penguatan Karakter 'Kerja Keras'}

Bentuk penguatan pendidikan karakter kerja keras yaitu upaya mengondisikan anak untuk berusaha pantang menyerah, mengerjakan sampai selesai dengan gembira (Kemendiknas, 2010; Mariyana, 2018). Tuturan direktif guru yang merupakan sarana penguatan ini yaitu:

(1) Ayo kita buat benderanya, pertama dibuat garis tegak dulu. Hallo, sudah? Coba selanjutnya atas garis bobok, samping garis lurus, bawah garis bobok. Panjangnya harus sama lho ya. Sudah?

(2) Coba gambarnya ondel-ondel dihitung sampai 7, semua dihitung 1,2,3,4,5,6,7,8,9,10. Coba kalau sudah semua sisanya disilang. Sisa berapa? Coba kalau sudah semua, sisa 3 disilang.

(3) Hadap kiri grak! Ayo angkat tanganmu ke atas, ke samping, ke depan. Dilanjutkan lagu untuk senam.

(4) Semua ikut gerakan ibu, geleng kanan geleng kiri; toleh kanan, toleh kiri.

(5) Bukune dibuka halaman 38. Bukane saka mburi ben cepet. (Caranya membuka dari belakang biar cepat)

(6) Urung banter, isih meneng wae. Sing putra oleh leren sik nggih, sing putri banter-banteran. (Masih belum keras, cebderung diam. Yang laki-laki diam dulu. Yang perempuan berlomba membaca dengan keras)

(7) (Ada gambar lambang sila-sila Pancasila, ada angka yang menunjukkan jumlah) Ayo Tarik garis sik! Tarik garis sesuai lambang bilangan!

(8) Memberi lemnya jangan banyak-banyak, yang penting lekat.

Tuturan direktif (1) Ayo, kita buat benderanya, pertama dibuat garis tegak dulu ... merupakan ajakan (dengan penanda ayo) pada siswa untuk menggambar bendera langkah demi langkah dengan contoh di papan tulis juga dengan pendampingan guru. Tuturan direktif ini mengondisikan siswa untuk mengerjakan tahap demi tahap untuk menyelesaikan pekerjaan menggambar bendera sampai menghasilkan karya gambar bendera. Hal ini merupakan 
penerapan metode praktik keterampilan mengembangkan karakter kerja keras.

Tuturan direktif (2) merupakan arahan pada siswa untuk mengikuti langkahlangkah yang dijelaskan guru. Siswa TK yang dalam tahap perkembangannya bersifat egonsentris (Mariyana, 2018) dituntut untuk memusatkan perhatian agar dapat memahami dan mengikuti secara praktik tahapan langkah (a) menghitung secara urut sampai 7 dari 10 ondel-ondel; (b) sisanya disilang; dan (c) menghitung sisanya. Langkah-langkah ini merupakan bentuk penanaman operasi pengurangan tahap dasar. Tuturan direktif ini mengondisikan pada siswa untuk melakukan dengan senang karena adanya gambar ondel-ondel sesuai tema. Tuturan direktif ini merupakan penerapan metode praktik keterampilan mengembangkan karakter.

Tuturan direktif (3) Hadap kiri grak! Ayo angkat tanganmu ke atas, .... merupakan arahan guru kepada siswa untuk memahami maksud dan kemudian mengikuti gerakan yang dilisankan dan dicontohkan guru. Kegiatan mendengarkan untuk memahami maksud dan sekaligus mempraktikkannya bagi siswa sulit dilakukan karena sifat egosentris pada anak usia dini sehingga diperlukan latihan secara intensif. Tuturan direktif ini merupakan penerapan metode praktik keterampilan mengembangkan karakter. Demikian juga tuturan direktif (4) merupakan arahan untuk senam. Tuturan direktif tersebut mendorong siswa melakukan aktivitas secara sungguhsungguh sesuai arahan guru. Tuturan direktif ini merupakan penerapan metode praktik keterampilan mengembangkan karakter kerja keras.

Tuturan direktif (5) Bukune dibuka halaman 38! merupakan suruhan untuk membuka buku sampai menemukan angka sesuai nomor yang disebut dan diperlihat- kan guru yaitu 38. Caranya dengan membuka buku dari belakang (dari halaman 42) agar cepat menemukan angka 38. Hal ini dilakukan karena bagi siswa, cara membuka buku dilakukan membuka halaman demi halaman. Tuturan direktif ini merupakan penerapan metode praktik keterampilan mengembangkan karakter kerja keras.

Tuturan direktif (6) 'Urung banter, isih meneng wae ...' merupakan arahan untuk mengaji ulang dengan lebih keras untuk siswa perempuan sementara yang laki-laki istirahat dulu. Arahan tersebut untuk melakukannya dengan berlomba agar lebih keras daripada yang lain sampai kegiatan mengaji dengan suara keras dapat terwujud. Kemudian giliran siswa laki-laki yang mengaji dengan cara yang sama. Tuturan direktif ini merupakan penerapan metode praktik keterampilan mengembangkan karakter kerja keras. Tuturan direktif (7) Ayo tarik garis sik! Tarik garis sesuai lambang bilangan! merupakan suruhan untuk menarik garis yang cocok antara lambang sila Pancasila (yaitu gambar: ka'bah, rantai, pohon beringin, kepala banteng, dan padi kapas) dengan angka 1-5 yang menunjukkan urutan sila-sila Pancasila sebagai dasar Negara Republik Indonesia. Dengan tuturan direktif ini, siswa terdorong untuk menyelesaikan tugasnya dan merupakan penerapan metode praktik keterampilan mengembangkan karakter kerja keras.

Tuturan direktif (8) Memberi lemnya jangan banyak-banyak, yang penting lekat berupa nasihat cara untuk mendapatkan hasil pekerjaan mengelem yang baik. Siswa perlu melakukannya dengan pelan, sabar, cermat dalam mengelem kertas dan mendorong siswa melakukan pekerjaan dengan baik sesuai nasihat guru. Tuturan direktif ini merupakan penerapan metode praktik 
keterampilan mengembangkan karakter kerja keras.

\section{Tuturan Direktif Sarana Penguatan Karakter 'Tanggung Jawab'}

Bentuk penguatan karakter tanggung jawab adalah menumbuhkan kesadaran pada diri anak untuk melaksanakan sesuatu dan menanggung sesuatunya (Kemendiknas, 2010; Mariyana, 2018). Tuturan direktif guru tersebut yakni:

(1) Sudah yang nulis hari tanggal? Nayla sudah nulis belum?

(2) Kalau sudah (nulis hari tanggal) coba tulisane ditebalkan dulu, hanya yang atas nanti yang bawah bareng bu guru, sudah?

(3) Hari ini kita menggambar bendera, kita mau menggambar bendera. Mbak Rosi tolong yang lain dibagikan bukunya!

(4) Pengumuman, besuk hari Rabu .... Coba dengarkan dulu, besuk pulangnya jam 0900 bu guru mau rapat. Nanti bilang bapak ibuk besuk dipapake jam 09 00. (dipapake= dijemput)

Tuturan (1) adalah tuturan direktif bertanya dari guru tentang tahap penyelesaian tugas yang diberikan dan terutama pada salah satu siswa. Fungsinya untuk mengingatkan kesadaran siswa dalam menyelesaikan tugas yang diberikan. Dan jika belum selesai bertanggung jawab untuk segera meyelesaikannya. Tuturan direktif guru ini sebagai bentuk penerapan metode penanaman karakter tanggung jawab dengan teknik balikan. Tuturan direktif (2) ... coba tulisane ditebalkan dulu, .... sudah? berupa suruhan dengan penanda coba. Selanjutnya, tuturan direktif bertanya, ..., sudah? menanyakan penyelesaian tugas menebalkan tulisan. Artinya, jika siswa sudah menyelesaikan dapat melanjutkan kegiatan berikut. Tetapi jika ada yang belum menyelesaikan diminta menyelesaikan untuk memenuhi tanggung jawabnya. Tuturan direktif ini merupakan bentuk pene- rapan penanaman karakter tanggung jawab dengan teknik koreksi.

Tuturan direktif (3) Mbak Rosi tolong yang yang lain dibagikan bukunya! berupa suruhan pada salah seorang siswa dengan meminta kesadarannya untuk melaksanakan tugas membagikan buku agar kegiatan semua siswa untuk menggambar bendera dapat terlaksana. Tuturan direktif ini merupakan bentuk penerapan metode praktik mengembangkan karakter tanggung jawab dengan teknik delegasi. Tuturan direktif (4) Nanti bilang sama bapak ibuk, besuk dipapake jam 0900 merupakan suruhan untuk memberitahukan kepada bapak/ibu masingmasing siswa tentang jam untuk menjemput karena pulang lebih awal. Tuturan direktif ini mengharuskan siswa dengan kesadaran melaksanakan tanggung jawabnya agar tidak salah waktu menjemput nantinya. Dengan demikian, tuturan ini merupakan sarana penerapan metode penanaman karakter tanggung jawab dengan teknik penjelasan.

\section{SIMPULAN}

Dalam interaksi pembelajaran di Taman Kanak-Kanak Aisyiah Karangwuni Polokarto Kabupaten Sukoharjo, guru melakukan aktivitas interaksi pembelajaran salah satunya dengan menggunakan tuturan direktif. Tuturan direktif yang diujarkan meliputi menyuruh, mengarahkan, pertanyaan, membolehkan, larangan, nasihat, dan mengajak. Tuturan direktif guru tersebut digunakan dengan tujuan pembiasaan perilaku siswa dalam pengembangan moral dan nilai-nilai agama, pengembangan sosial, pengembangan emosional dan kemandirian sesuai kurikulum yang berlaku. Dengan penelitian ini, ditemukan bahwa tuturan direktif tersebut mengondisikan pendidikan karakter anak TK yang mencakupi: (1) cinta terhadap Tuhan Yang 
Maha Esa; (2) toleransi dan cinta damai; (3) jujur; (4) disiplin; (5) percaya diri; (6) mandiri; (7) kreatif; (8) kerja keras; dan (9) tanggung jawab.

Tuturan direktif guru dalam pembelajaran sebagai sarana penguatan karakter diidentifikasi adanya penggunaan beberapa metode yaitu metode (1) penanaman nilai; (2) keteladanan atau peragaan nilai; dan (3) praktik keterampilan nilai. Penggunaan metode tersebut ada yang tidak bersifat tunggal tetapi dipilih yang lebih dominan penerapannya menurut penulis.

Ada beberapa tuturan direktif yang ternyata dapat berfungsi sebagai sarana untuk menguatkan lebih dari satu karakter, seperti pada tuturan Mari berkemas-kemas. Tuturan direktif tersebut berupa ajakan untuk mengemasi alat pelajaran masingmasing dan disimpan di tempatnya untuk digunakan lain waktu. Tuturan direktif ini mengondisikan penguatan karakter 'mandiri'. Selain itu, tuturan direktif tersebut juga berupa ajakan demi terciptanya suasana tertib yang merupakan penguatan karakter 'disiplin'.

Pada masa pandemi yang pembelajaran tatap muka tidak dapat dilaksanakan sejak pertengahan Maret 2020 mengakibatkan kerinduan pada interaksi pembelajaran yang penuh dengan isi pendidikan, yakni pembelajaran luring (luar jaringan). Perlu adanya pengganti model pembelajaran yang dapat dilaksanakan untuk pendidikan anak usia dini dalam pembentukan karakternya di era pandemi Covid19 seperti sekarang ini.

\section{UCAPAN TERIMA KASIH}

Atas terwujudnya artikel ini sampai diterbitkan, penulis menyampikan terima kasih terutama kepada pengelola Jurnal Pendidikan Karakter dalam mengapresiasi pemikiran ini. Selanjutnya, terima kasih juga disampaikan kepada pengumpul data dan guru TK Aisyiyah Karangwuni Polokarto Kabupaten Sukoharjo yang telah memfasilitasi peneliti dalam pengumpulan data.

\section{DAFTAR PUSTAKA}

Affandi, I. (2020). Pembentukan karakter anak sejak dini melalui dongeng calon arang oleh Pramoedya Ananta Toer. Jurnal Pendidikan Karakter, 10(2), 197-216. DOI: https://doi.org/10.21831/jpk.v10i2.31973.

Efendi, A. (2020). Nilai karakter dalam novel Biografi 'Hatta: Aku Datang karena Sejarah'. Jurnal Pendidikan Karakter, 10(1),14-32. DOI: https://doi.org/10.21831/jpk.v10i1.31269.

Fransisca, L., Clara, P.A. (2015). Keterkaitan antara moral knowing, moral feeling, dan moral behavior pada empat kompetensi dasar guru. Jurnal Kependidikan, 45(2), 211-221. DOI: https://doi.org/10.21831/jk.v45i2.7500.

Goleman, D. (1995). Emotional intelegence. New York: Bantam Book.

Hidayani, T. A. (2019, Juni 4). Efek kebiasaan buruk mengisap jari pada balita dan anak-anak. KSM Gigi dan Mulut. RSUP Dr. Sardjito Yogyakarta. Sardjito.co.id.

Ibrahim, A.S. (1993). Kajian tindak tutur. Surabaya: Usaha Nasional.

Kemendikbud. (2016). Konsep dan pedoman penguatan pendidikan karakter di sekolah dasar dan sekolah menengah. Jakarta: Kemendikbud RI.

Kemendikbud. (2017). Peta jalan penguatan pendidikan karakter. Jakarta: Kemendikbud RI. 
Kemendiknas. (2011). Panduan pelaksanaan pendidikan karakter. Jakarta: Badan Penelitian dan Pusat Kurikulum dan Perbukuan Kemendiknas RI.

Kemendiknas. (2010). Pengembangan pendidikan budaya dan karakter bangsa. Jakarta: Badan Penelitian dan Pengembangan Pusat Kurikulum Kemendiknas RI.

Kirschenbaum, H. (1995). 100 ways ti enhance values and morality in schools and youth setting. Massachusetts: Allyn \& Bacon.

Lickona, T. (1991). Educating for character: How our schools can teach respect and responsibility. New York: Bantam Book.

Listiawati. N. (2018). The implementatuion of strengthening caracter education in SDN 09 Mataram City Nusa Tenggara Barat. Jurnal Pendidikan Karakter, 7(1), 17-28. DOI: https://doi.org/10.21831/jpk.v8i1.21668.

Mariyana, R. (2018). Kompetensi guru dalam pembelajaran berbasis pendidikan karakter untuk anak usia dini. Pedagogia, Jurnal Ilmu Pendidikan, 8(1), 17-28. DOI: https://doi.org/10.17509/pedagogia.v12i1.3296.
Masitoh. (2012). Strategi pembelajaran TK. Jakarta: Universitas Terbuka.

Meilani, E. (2020). Analisis muatan nilai karakter dalam buku teks Bahasa Indonesia kelas XI kurikulum 2013 revisi 2017. Jurnal Pendidikan Karakter, 10(2), 258-273. DOI: https://doi.org/10.21831/jpk.v10i2.35165.

Prasetyo, D. \& Marzuki. (2016). Pembinaan karakter melalui keteladanan guru pendidikaan kewarganegaraan Sekolah Islam Al Azhar Yogyakarta. Jurnal Pendidikan Karakter, 6(2), 215-231. DOI: https://doi.org/10.21831/jpk.v6i2.12052.

Rustono. (1999.) Pokok-pokok pragmatik. Semarang: UNNES Press.

Sudaryanto. (2015). Metode dan aneka teknik analisis bahasa. Yogyakarta: Sanata Dharma University Press.

Syah, M. (2008). Psikologi pendidikan dengan pendekatan baru. Bandung: PT Remaja Rosdakarya.

Tarigan, H. G. (2009). Pengajaran pragmatik. Bandung: Angkasa. 